\title{
Michigan Sustainability Case: Rural Electrification: Which Infrastructure Is Best for the Brazilian Pantanal?
}

\author{
Elizabeth Oliphant, ${ }^{1, *}$ Austin Broda, ${ }^{2, * *}$ and Adam C. Simon ${ }^{1,3}$
}

\begin{abstract}
Nearly one billion global citizens lack access to reliable electricity, with the majority being residents of developing countries. The absence of reliable electricity impacts a wide variety of things including the ability to refrigerate vaccines and other medical supplies, improve educational achievement, and reduce poverty. Access to reliable electricity has also been shown to improve gender equality and reduce intimate partner violence. This article highlights the challenges associated with electricity infrastructure development in developing countries by focusing on the Brazilian Pantanal. The benefits and challenges of conventional, centralized hydroelectricity and coal-fired power plants, which require long-distance electricity transmission, are compared with a solar microgrid that can operate independently at the local scale. The article provides appropriate background to allow students to understand the complexities surrounding energy development and engage in the decision-making process through the lens of local stakeholders as they decide which energy infrastructure offers the best future for rural communities.
\end{abstract}

Keywords: coal-fired power plant; developing countries; energy infrastructure; hydroelectricity; solar microgrid

\section{Background}

This case study is part of the Michigan Sustainability Cases collection. Michigan Sustainability Cases (MSC) is an initiative housed in the School for Environment and Sustainability at the University of Michigan producing case studies for sustainability education. Since 2016, MSC has produced 33 case studies, each one written by a team of students, faculty, and practitioners. The case studies cover a wide variety of sustainability topics, from wildlife conservation to sustainable agriculture to waste management. Finished case studies are presented on an online learning platform called Gala (learngala.com), allowing the cases to use multimedia elements, such as embedded videos, images, maps, and links, to create a more interactive experience. Each case also includes an engaged learning exercise that helps students to analyze a case or teaches a critical skill. Through its program and platform design, MSC seeks to bring the case method to new audiences and make case-based learning more immersive, adaptable, and inclusive. The platform became open to all contributors beginning in 2018 with the launch of the author tools feature, which enables anyone to create and share a case. Readers are invited to explore Gala and contribute their own sustainability stories.

The goal of this case study is to educate students about the environmental, economic, and social impacts

\footnotetext{
'Department of Earth and Environmental Sciences, ${ }^{2}$ Department of Mechanical Engineering, ${ }^{3}$ Program in the Environment, University of Michigan, Ann Arbor, Michigan, USA.

*Current affiliation: Fulbright Association, Indonesia.

**Current affiliation: FCA Fiat Chrysler Automobiles, Dundee, Michigan, USA.
}

(C) Elizabeth Oliphant et al., 2020; Published by Mary Ann Liebert, Inc. This Open Access article is distributed under the terms of the Creative Commons Attribution Noncommercial License (http://creativecommons.org/licenses/by-nc/4.0/) which permits any noncommercial use, distribution, and reproduction in any medium, provided the original author(s) and the source are credited. 
of different grid systems and sources of energy generation. Students are asked to become decision makers and determine which energy system is right in the community of Porto Jofre, Brazil. The intended audience for this case study is first- and secondyear university students in environmental studies and energy policy.

\section{Introduction}

In 2020, nearly 900 million people throughout the world lived without access to electricity, almost 90 percent of whom live in rural areas lacking electricity. Nearly all countries in the world have policies that emphasize improving access to electricity for their citizens. While the need for expanding energy access is recognized across the world by governments and individuals alike, the question that still remains is how to ensure access, and with what infrastructure.

While needs differ throughout the world, there are three general strategies for developing and extending energy infrastructure: city grid expansion, construction of a localized microgrid, or installation of standalone mini grids. City grid expansion involves building electrical transmission lines to connect to centralized power plants, which may be hundreds of kilometers away. In comparison, a microgrid operates independently of established power infrastructure, and it generates and distributes power locally. Microgrids, unlike mini grids, have potential for being connected to other microgrids as well as city infrastructure, but integration presents its own challenges. A mini grid is a small system that usually operates for a single house or building. This case study analyzes the viability of city grid expansion versus building a solar microgrid to improve electricity access in the community of Porto Jofre (Figure 1).

Porto Jofre is a rural community in the Brazilian Pantanal, the world's largest tropical wetland and a biodiversity hotspot. The beautiful and natural tropical region is characterized by intense seasonal rainfall and a vast variety of plants and animals such as capybara, caiman, and jaguar. Due to its remote location, the community has lived for years with minimal electricity access. The systems that do exist are largely powered by diesel generators or solar mini grid systems. To obtain fuel for these generators, residents must travel hours either by boat or by car along the bumpy dirt road that is the

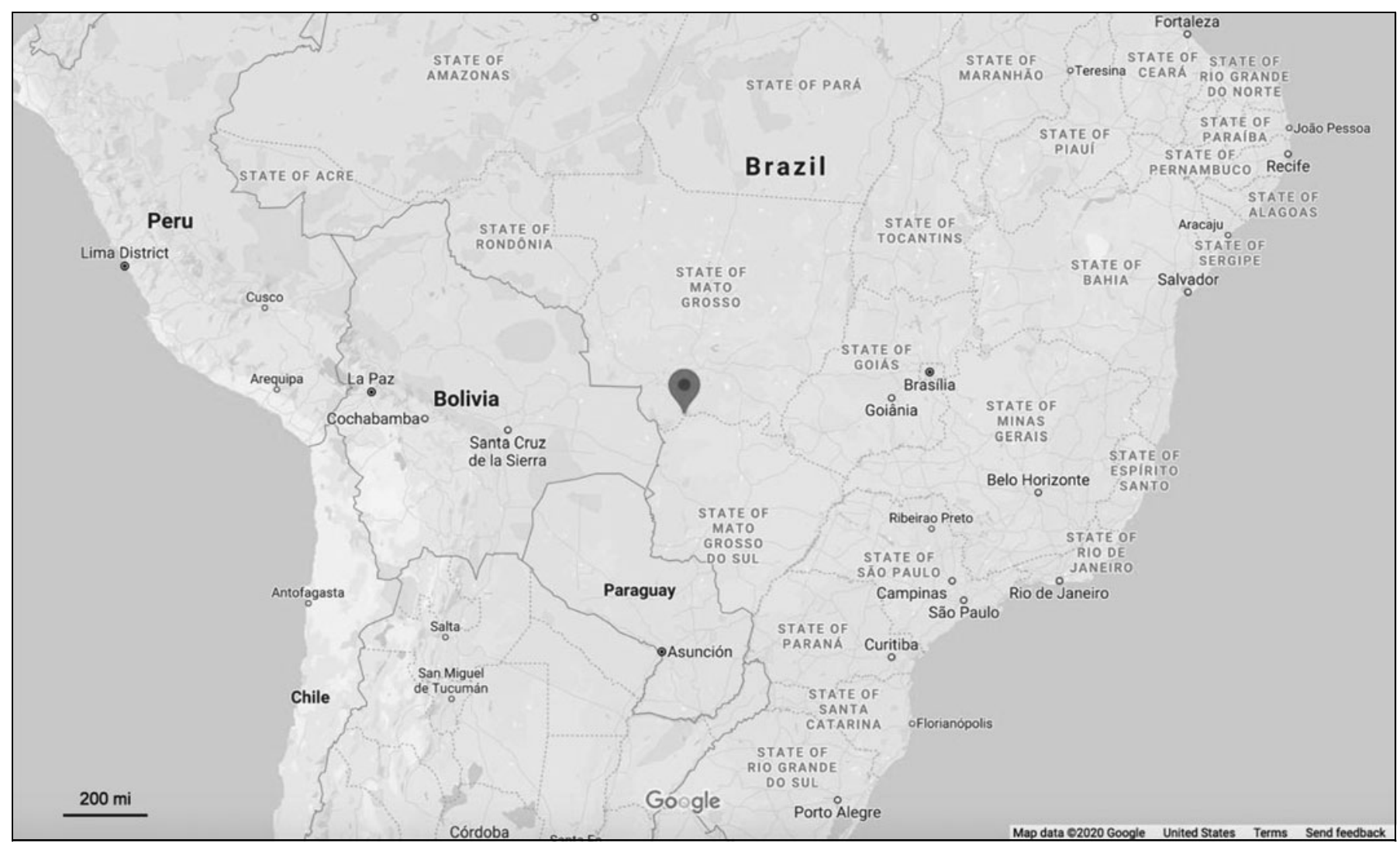

Figure 1. Porto Jofre in the Brazilian Pantanal 
Transpantaneira Highway. For residents in Porto Jofre and the surrounding areas, the situation is all about to change. Energisa, the local energy commission, has decided to build energy infrastructure to service Porto Jofre. The question they face is, What type of energy infrastructure is best for this environment and the people in it?

The decision maker in this case study is João Oliveira, the head of the Energisa branch in the area. Students are asked to weigh the options at hand and decide, if they were in his position, which energy infrastructure they would invest in. To make this decision, students must consider the environmental impacts of the energy sources used, the cost of building each type of infrastructure, the reliability of each of the systems, and the logistics of how different systems will be built and maintained. This case study challenges students to consider the factors related to expanding energy infrastructure in the Pantanal area, which are also applicable to other rural areas. This case also exposes students to some of the technical aspects of energy generation and transmission.

\section{Case Study Introduction}

In 2017, the average American residential utility customer used 10,972 kilowatt-hours (kWh) of electricity, ${ }^{1}$ enough electricity to run a standard 12 W LED light bulb continuously for 100 years. In the same year, 12 percent of the world's population, over one billion people, still did not have access to electricity. ${ }^{2}$ In rural communities, nearly one out of four households lack access to electricity. Without access to electricity, industrial productivity is restricted, vaccines cannot be refrigerated, and people often rely on wood-burning stoves, despite the high levels of indoor air pollution they cause. Due to these concerns, expanding access to electricity has been a goal of many governments and is one of the 17 Sustainable Development Goals of the United Nations.

In many cases, achieving this goal can be difficult due to the remote nature of off-grid communities and the high cost of energy infrastructure needed for electricity transmission or generation. Additionally, the path to universal electricity access involves choosing among many types of energy systems, each with its own costs and benefits. Government officials are thus left to choose what type of system to invest in-officials such as João Oliveira, the local head of the energy committee in Poconé, Brazil.

\section{Into the Pantanal}

The sun set above the Brazilian Pantanal (Figure 2). Darkness crept from the fringes of the sky and revealed a clear view of the Milky Way galaxy untouched by light pollution. Macaws grew quieter as they settled in for the night and the groan of diesel generators began. Diesel generators, solar energy systems, and lack of electricity were all common in the Pantanal, for many people did not have access to electricity from the city. However, this situation was about to change for the residents of a small Pantanal town called Porto Jofre (see Figure 1).

Porto Jofre is a town located at the heart of the Brazilian Pantanal, the world's largest tropical wetland and a UNESCO World Heritage site that is famous for having the world's highest concentration of jaguars, which can be seen along the Cuiabá River (Figure 3). In many cases in the Pantanal, rivers act as roads because much of the Pantanal is accessible only by boat. However, Porto Jofre is an exception; it is located both on the Cuiabá River and the Pantanal's only major road, the Transpantaneira Highway (Figure 4). The Transpantaneira Highway is a long dirt road that serves as the main thoroughfare into the Pantanal from the city of Poconé and the rest of the state of Mato Grosso, Brazil. Along this road, striking flora and fauna capture the attention of travelers, such as caiman, capybara, and macaws that are

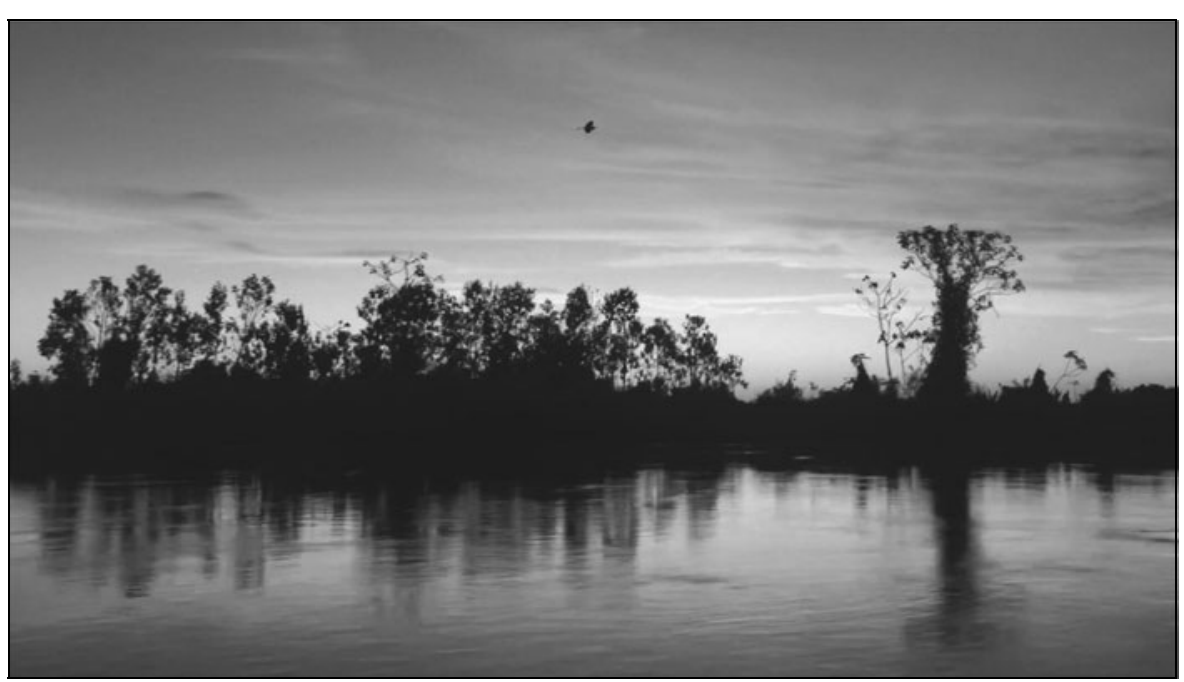

Figure 2. Sunset in the Brazilian Pantanal wetlands 


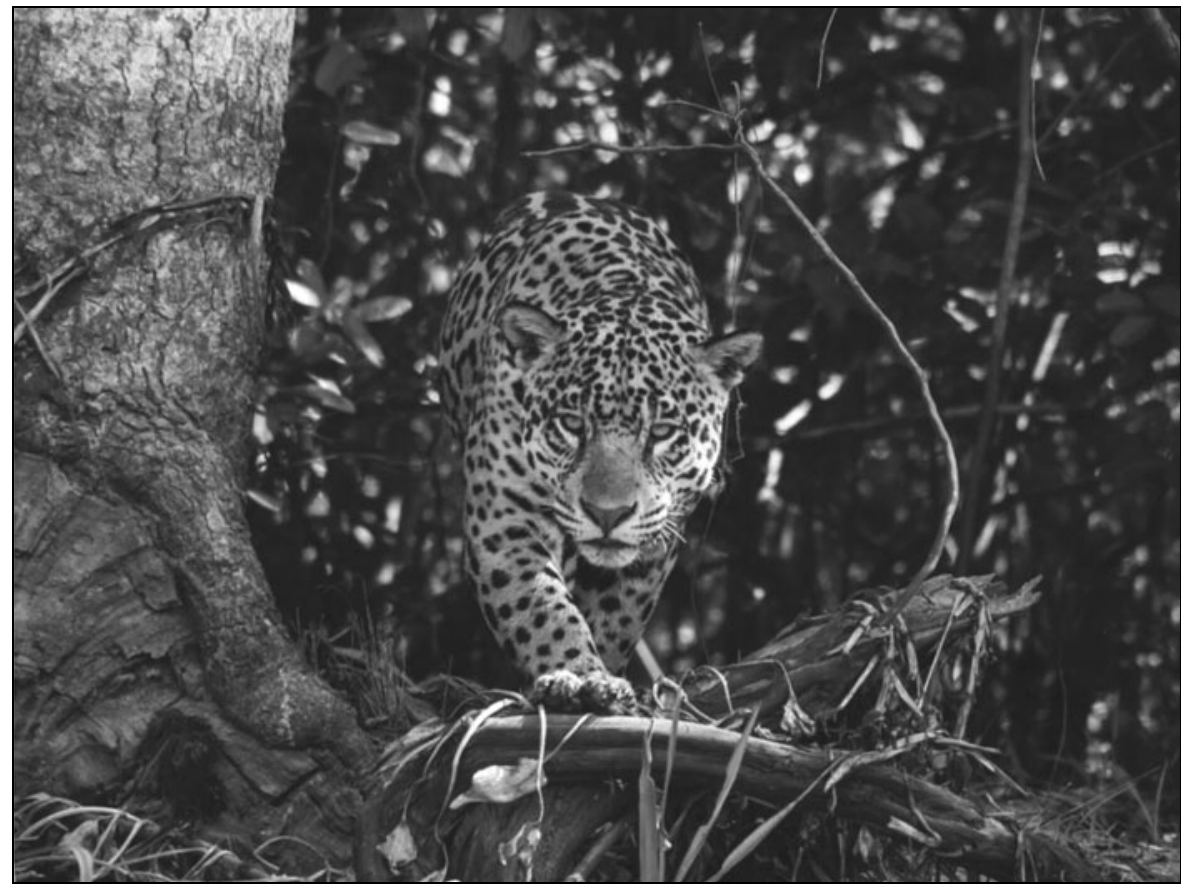

Figure 3. The jaguar is one of several big cats that inhabit the Pantanal.

juxtaposed with tourist lodges and fazendas with their herds of cattle.

Porto Jofre is near the end of the Transpantaneira Highway, and the community has about 50 residents, a school, an environmental research

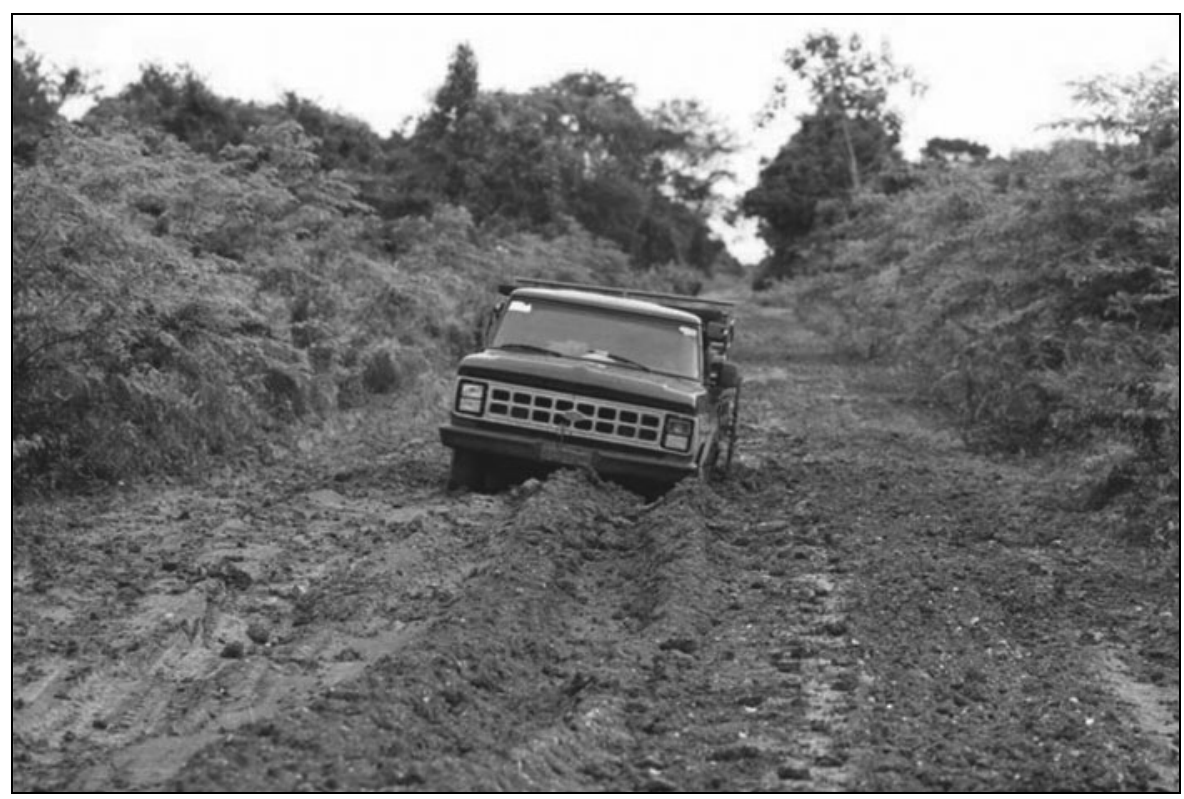

Figure 4. The Transpantaneira Highway in 2011 hours each way to Poconé. Other Pantanal towns experienced the same problem, and for some, the journey to purchase fuel was five hours each way by boat. This process wasted fuel and time, and residents wanted change. To reduce their reliance on diesel generators, the community of Porto Jofre applied for electricity infrastructure to be built by their local energy committee, Energisa, in Poconé.

\section{A Decisão de João (João's Decision)}

João Oliveira was the local head of energy infrastructure at Energisa in Poconé. Six months ago, the Porto Jofre case was put on his desk; now his responsibility was to see that the town's residents got access to the electricity they needed. Initial consideration of the project revolved entirely around costs. Electricity infrastructure was expensive, and the local budget was already stretched thin.

For this project, João decided to apply for federal funding from a program called Luz para Todos, which translates as Light for All. This program, originally started by former president Dilma Rousseff in 2003, ${ }^{3}$ was part of the Brazilian federal government's plan for universal access to electricity. As of 2018, over 16 million Brazilians had received improved electricity access through Luz para Todos projects, and the program had been extended until at least 2022. João was hoping this program could also help him improve electricity access for the residents of Porto Jofre.

After weeks of waiting, João finally received the news that Luz Para Todos would fund this project! With funding secured, the real question 


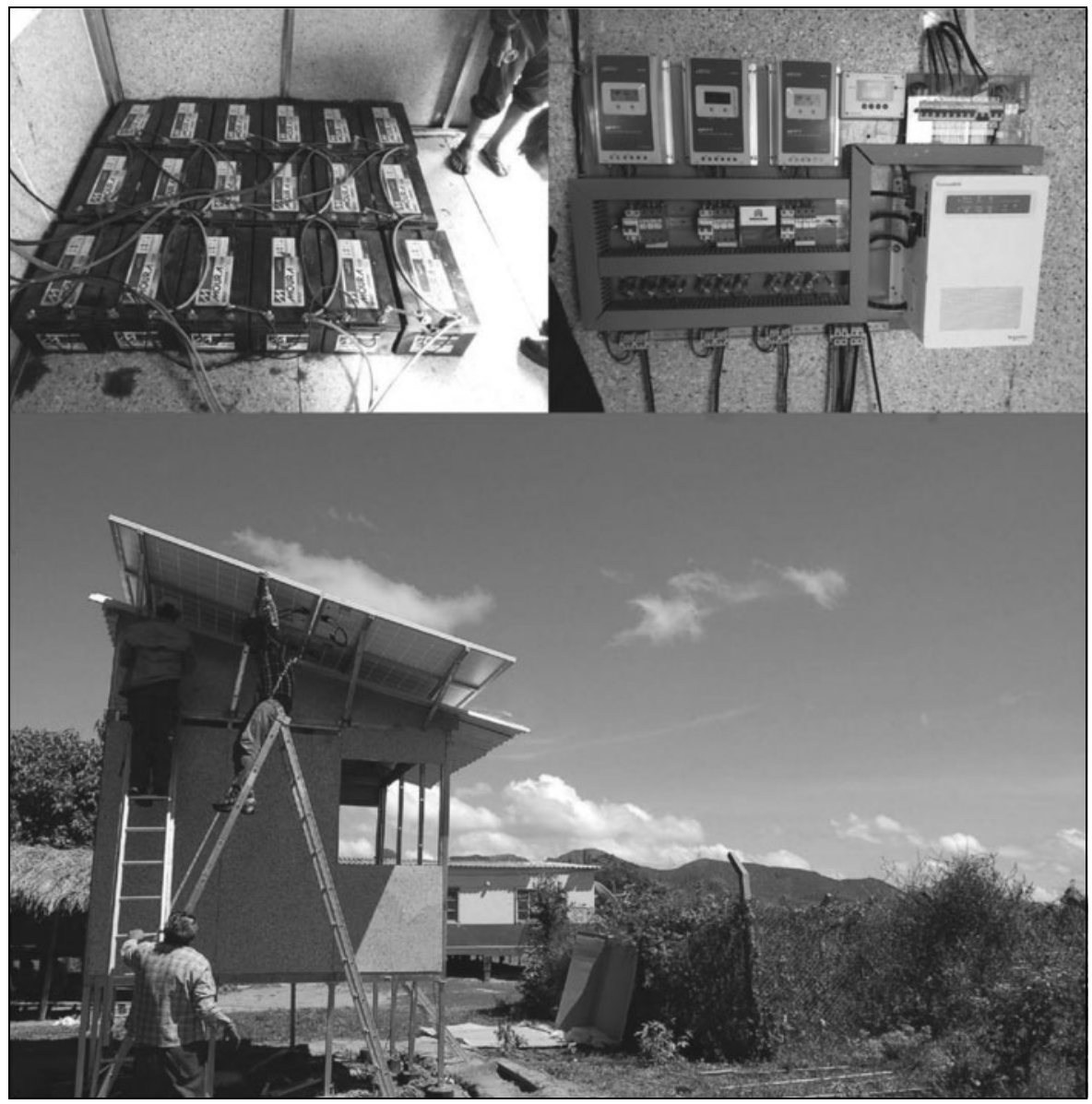

Figure 5. A shared solar energy system in the Pantanal

now lay before him: What type of energy infrastructure should he invest in for the expansion of energy access to the people of Porto Jofre? Before him he had two plans laid out: one was for expanding the city grid from Poconé to Porto Jofre, a distance of approximately 90 miles, or 150 kilometers; the other was for a solar microgrid system.

A solar microgrid is a network of solar panels that generates power locally. Luz para Todos projects in the past had typically involved expanding the city grid to locations where residents wished to receive grid access. This meant that there was already a well-defined legal process for city grid expansion projects, which João expected would make the entire process easier. Places that wished to receive city grid access simply applied at their local Energisa office. Following the initial application, Energisa would send out an evaluation team to analyze the costs and needs related to the specific grid expansion. For Porto Jofre, the nearest Energisa office was located in Poconé.

The school in Porto Jofre would qualify as a high-need location, and the expansion of the city grid would likely begin with power lines installed from Poconé to the school. After this installation, local Porto Jofre residents would need to travel to Poconé to apply for transmission lines to be built between the school and their houses or tourist lodges.
For some, this would be a simple trip into Poconé, followed by waiting some time for the evaluations. For others, completing application paperwork would be more difficult, as levels of literacy and access to transportation varied throughout the Pantanal.

The other option was to pursue a new, decentralized approach to electricity involving solar microgrids (Figure 5). Past microgrid projects had been funded by local and international NGOs, and there were a few in the Pantanal. Three hours downriver by boat from Porto Jofre, the community of Barra de São Lourenço used a solar microgrid to provide electricity to its residents. The system powered small household appliances such as lights and fans, and a shared community freezer for the residents. The nonprofit Ecoa had funded this project, and a village resident was trained to maintain the system and administer the distribution of electricity to the residents. If João chose to employ a solar microgrid system for the community of Porto Jofre, he would likely use Barra de São Lourenço's system as a model for how community sharing of this resource could work.

João had made decisions like this in the past; each time the situation was distinct, but every time the decision was important to individuals and communities. His decision would change the lives of the people living in Porto Jofre by helping community members to expand their tourism businesses, alleviate concerns, increase internet access, and ultimately change the way that Porto Jofre used electricity.

Before making his decision, João wanted to gain a more technical understanding of how each type of 
infrastructure generated electricity. $\mathrm{He}$ also wanted to better understand the environmental and economic consequences of conventional city grids versus microgrids. With this information, he could better assess the pros and cons for each type of system in order to determine which system would be best for Porto Jofre.

\section{City Grid Expansion}

João sat at his desk contemplating the plans laid before him. His fan hummed as it provided relief from the year-round $92^{\circ} \mathrm{F}\left(33^{\circ} \mathrm{C}\right)$ heat. However, João's fan could not provide him with relief from the heat of this decision.

If João chose to expand the city grid, residents would receive electricity from the Poconé and greater Cuiabá city grid. Twenty-five percent of the city's electrical grid was generated from fossil fuel power plants, and the remaining 75 percent was generated from large hydropower plants. ${ }^{4}$ Given that most of the city grid's electricity was generated from hydropower plants, João decided to take a closer look at hydroelectric power generation and the impacts these facilities had on the environment.

\section{Hydropower and the Environment}

Hydropower utilizes the power of gravity and falling water to create electrical energy. A typical hydropower plant contains a large body of water controlled by a dam. The dam releases water from a higher elevation, allowing the water to flow downstream. As it flows down, the water spins a turbine, converting the water's kinetic energy into mechanical energy. A generator then turns this mechanical energy into electricity that can be used by houses and businesses.
Unlike fossil fuels, hydropower electricity is carbon neutral, not considering initial dam construction and continued maintenance. João noted that the predicted lifetime greenhouse gas emissions per unit of energy produced by hydropower is approximately 26 grams of $\mathrm{CO}_{2}$ per $\mathrm{kWh}$, compared to coal, which is 888 grams of $\mathrm{CO}_{2}$ per $\mathrm{kWh}$, or natural gas, which is 499 grams of $\mathrm{CO}_{2}$ per kWh. ${ }^{5}$ In 2016, as part of the Paris Agreement, Brazil agreed to reach peak carbon emissions by the year 2030 and decrease emissions sharply thereafter. ${ }^{6}$ To achieve this goal, Brazil was continuing to build more small- and large-scale hydroelectric generation sites. In 2018, Brazil had the world's second largest hydropower dam, the Itaipu Dam on the border of Brazil and Paraguay.

Despite the low carbon emissions of hydroelectric power, the construction of large hydroelectric dams often drastically disrupts the ecosystems of the rivers on which they are built. In Brazil, the construction of the Belo Monte Dam on the Xingu River transformed forests and lowlands surrounding the reservoir into floodplains. ${ }^{7}$ Flora and fauna endemic to the Xingu River suddenly faced a completely different ecosystem, and indigenous peoples like the Munduruku, whose way of life depended on the river ecosystem, had to adapt to the changing watershed.

\section{Solar Microgrids}

The community of Barra de São Lourenço convinced João that community-shared solar microgrids could work in the Brazilian Pantanal, but João had questions about the technical aspects of solar microgrid operation. He knew he needed to better understand how solar cells generate electricity, what a microgrid is, and what maintenance is necessary for this type of system.

\section{Solar Energy and the Environment}

In recent years, João had heard solar energy praised as renewable energy for the future. Solar electric systems utilize the power of the sun to create energy, much like plants. When sunlight strikes the surface of a solar panel, it causes the semiconductor material in the panel to give off electrons; this is known as the photoelectric effect. ${ }^{8}$ The free electrons from this semiconductor material are then drawn down through wires attached to the solar panel creating a direct current (DC). Inverters receive DC electricity from wires connected to solar panels and convert it into alternating current (AC) electricitythe current used to run most home appliances. A charge controller regulates the voltage of the AC electricity output, avoiding overpowering appliances. The charge controller also regulates the input to batteries during charging; overcharging batteries can significantly reduce their functional life. ${ }^{9}$

Since solar energy utilizes the power of the sun, it is carbon neutral (not considering emissions due to maintenance and construction of these systems). Carbon emissions from solar energy are 85 grams $\mathrm{CO}_{2}$ per $\mathrm{kWh}$, making it higher than that of hydropower $(26 \mathrm{~g})$, but lower than fossil fuels (499-888 g). ${ }^{5}$ Additionally, installation of solar panels does not permanently or dramatically alter the environment, unlike the construction of hydropower dams. Solar panels can be removed at any time and can be built on existing buildings to maximize space. For enough panels to power Porto Jofre, João realized that some panels would need to be built on 
herding or farming land. Residents would need to be compensated for their land, but most Porto Jofre residents were fishermen, so the placement of these panels would not greatly affect their businesses.

Despite low carbon emissions and location impact, there were environmental concerns associated with the creation of solar panels. To create thin-film solar panels, rare earth elements are needed. ${ }^{10}$ These rare earth elements (REE) are mined halfway around the world, primarily in China, which in 2018 supplied 93 percent of the global REE market. The supply of REE is also finite, but solar panels use small amounts of REE. Running out of REE is not the current concern, but disruption in the supply chain could have serious effects on the global economy and politics. In addition, João learned, the rare earth elements used in solar panels and other technology such as cell phones are rarely recycled. With the growing market for the technology, a method to recycle REE would need to be developed before running out became a risk.

In addition to REE, solar panels often contain lead, cadmium, and other toxic chemicals that can cause chemical leaching into the soil and groundwater if the solar panels are not properly disposed of. ${ }^{11}$ The heavy rainfall and seasonal flooding in the Pantanal also meant there was a risk of storms damaging the panels and causing chemical leaching. The solar energy system in Porto Jofre would have to be built in a protected place, and a clear disposal system for the solar panels would have to be created.

As of 2018, the market for solar was growing rapidly largely due to decreasing costs, improving technology, and site placement flexibility. Solar electricity is less site specific than renewables such as geothermal or hydropower because solar can be used in any location where there is consistent sun. The Pantanal is one such place, having an average of 179 sunny days a year ${ }^{12}$ and a latitude of $16^{\circ}$ south, where the sun's intensity is not as seasonal as at higher latitudes. ${ }^{13}$ On average the Pantanal receives about $5.1 \mathrm{kWh} / \mathrm{m}^{2}$ of sunshine per day, ${ }^{14}$ but despite a high average insolation, some months, such as February, have little sunshine due to cloud cover. Lack of sunshine for days at a time could affect electricity availability and access for the people of Porto Jofre. João was concerned about receiving complaints from lodges, research stations, and others that required constant power and could have issues with the community solar microgrid.

After several hours of research, João needed a coffee break. He set down his plans, strolled over to the coffee tumbler, and filled his cup. In rural Brazil, coffee is often served very sweet and in cafezinho cups that are smaller than the height of your fist. A sip of sugary goodness and his cup was gone. It wasn't much, but it gave him some clarity and a chance to regroup.

\section{Transmission}

Transmission lines from the point of electricity generation to the residents of Porto Jofre would be needed whether João chose to expand the city grid or install a solar microgrid. The distance spanned by these transmission lines differed greatly between the two plans, however, so João's environmental considerations would have to include the effects of these transmission lines on electricity provision, maintenance costs, and wildlife.

\section{City Grid and Transmission Lines}

If João chose to expand the city grid, the transmission lines would need to be built from Poconé to Porto Jofre (Figure 6). These transmission lines would be built along the Transpantaneira Highway so that any residents of fazendas or tourist lodges along the highway could potentially connect to grid electricity. Additionally, once the transmission lines were built to Porto Jofre, there would be potential for future projects to expand the grid farther into the Pantanal. That meant that with this infrastructure plan, João might be able to expand access to more communities and make a difference in more people's lives, albeit with environmental consequences. This potential for future expansion was one main reason past Luz para Todos projects had focused on expansion of the grid line.

On the downside, João learned from a quick Google search that longer transmission distances result in more energy lost due to transmission line resistance. In Brazil, approximately 15 percent of energy generated in 2015 was lost in transmission. ${ }^{15}$ João was surprised to learn losses were only 15 percent, but he also considered that because Porto Jofre was farther from Pocone than most municipality grids, the system would experience higher electricity losses. To minimize the inefficiency of transmission lines, João could invest in high-voltage power lines, but due to high cost and wetland terrain, high-voltage power lines along the Transpantaneira Highway were likely impractical.

In addition to energy loss, João was concerned about maintaining the transmission lines in a tropical wetland environment such as the Pantanal. The Pantanal's wet season runs 


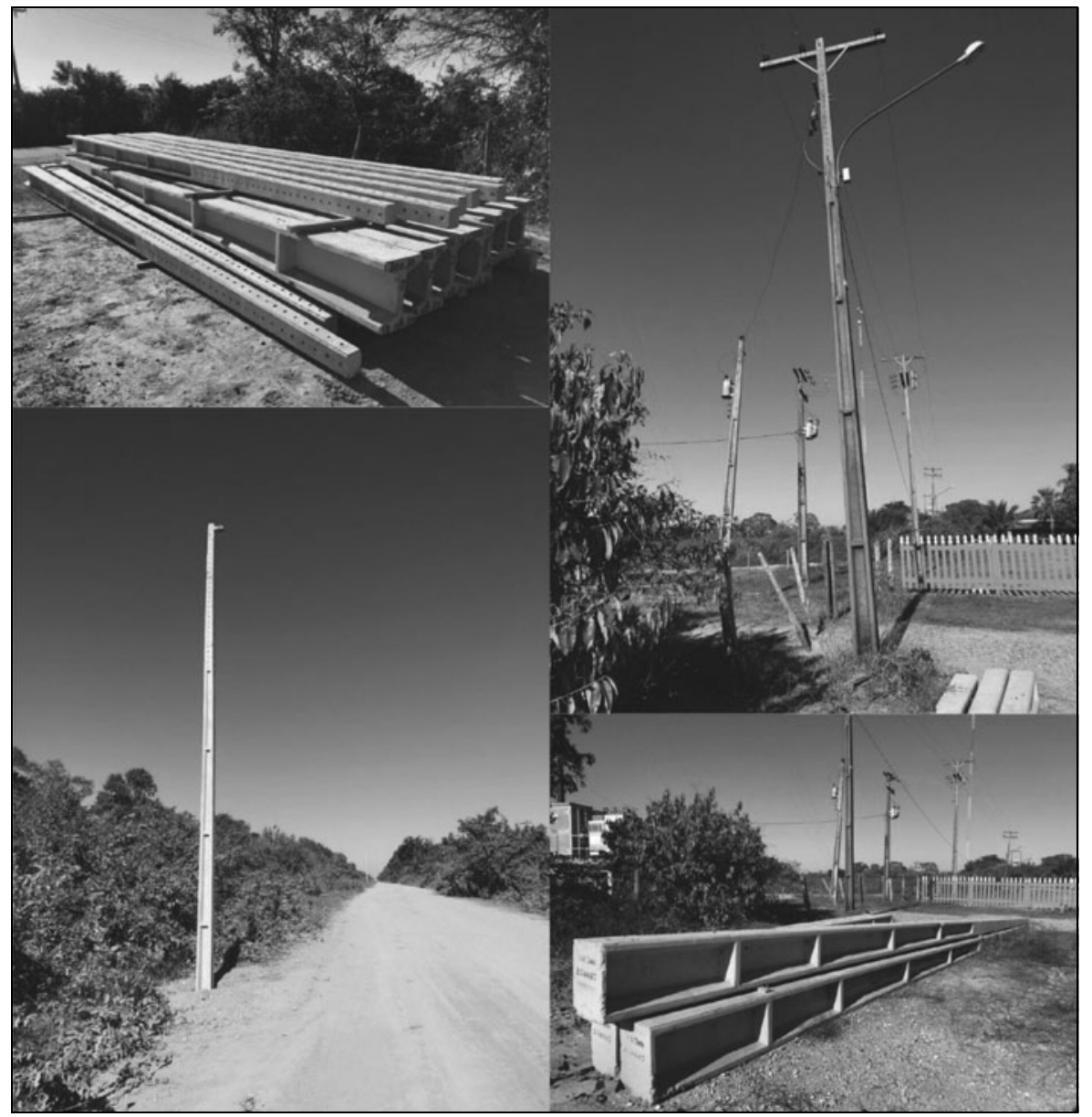

Figure 6. Construction materials for installing transmission lines

from October to March during which time the area receives an average total of more than 30 inches of rain, which is about 75 percent of the region's total yearly rainfall. ${ }^{16}$

Many of the Pantanal's major rivers and tributaries overflow in the rainy season, causing flooding in the area. Because of the wetland environment and heavy seasonal rainfall, people have adapted by using more water-resistant building materials. The transmission poles João would use are made of fiberglass, which is more water-resistant than wooden poles like those commonly used in the United States.

Even with the proper materials, João was still worried about power outages caused by wire failure. He knew that power line failure could result in a domino effect in which everyone farther down the line would lose power. These issues could be difficult to fix as road conditions during the wet season make travel along the Transpantaneira Highway nearly impossible. For example, in 2018 the Transpantaneira Highway flooded and made Porto Jofre inaccessible by car for months. This flooding was so extensive that it actually formed a new lake. Transmission line failure during one of these heavy rainstorms could mean power might take days to weeks to be restored.

João also considered another environmental concern: the impact of newly constructed electric transmission lines on wildlife. He was happy to learn that transmission lines do not greatly divide habitats; in fact, birds such as the jabiru stork, for which the Pantanal area is famous, use the poles to build their nests. Despite these facts, João knew that increased access to electricity could mean further development in the area, which could alter habitats and threaten food supply for wildlife.

\section{Microgrids}

Unlike the city grid expansion plan, if João chose to utilize solar energy for Porto Jofre, the town would not need long transmission lines from Poconé; instead, the town would have its own solar microgrid that would require transmission only over a small area. Microgrids were usually used to power small communities or individual residents. João was keen to learn more about why many off-grid communities in the Pantanal, such as Barra de São Lourenço, were utilizing microgrids. It turned out that microgrids experienced little to no energy loss in transmission. They generated and used electricity locally, so the transmission lines connecting the solar panels to residents were very short. Additionally, each microgrid was independent; therefore, if one microgrid was damaged or failed, the surrounding microgrids were not affected, unlike city grids where power outages had a domino effect.

Microgrid installation in places with hurricanes, earthquakes, or floods can help create natural disaster resilience. However, if there were to be a maintenance issue with Porto Jofre's microgrid, it could be more difficult to get technicians all the way to Porto Jofre, and it might take longer for the issue to be reported to Energisa. Additionally, with this decentralized 
and independent approach, economies of scale that large centralized power plants achieve could not be realized, and some costs were higher.

\section{System Costs}

\section{Grid Expansion Costs}

Although environmental concerns were important, João could not ignore the costs associated with each type of infrastructure. One of the major costs associated with connecting Porto Jofre to the city grid would be building the transmission lines. The cost per kilometer of transmission line in Brazil varied from approximately $\mathrm{R} \$ 150$ to $\mathrm{R}$ $\$ 1,600 .{ }^{17}$ This variation was a result of many factors, such as the number of homes the lines would serve, type of environment, and type of transmission lines. Wetland environments were more expensive to build on, and there was only a small window of time when the land was dry enough for building in the wetland. If the window were missed, the project would be delayed by weeks, and costs would increase. Based on the environment, size of the community, and distance, João estimated that building transmission lines would cost approximately $\mathrm{R} \$ 550$ per kilometer, and each river crossing would cost an additional $\mathrm{R} \$ 1,000$. Transmission line maintenance would incur additional expenses as well.

In addition to the cost of the transmission lines, João knew that there were also upfront costs with building hydroelectric dams. While expanding to Porto Jofre would not require building a whole new hydroelectric dam, it would exert additional strain on the city grid. And if more communities hooked up to the grid, more hydroelectric dams would need to be built. As of 2018, Brazil had spent over (U.S.) $\$ 50$ billion constructing hydroelectric dams like the Belo Monte Dam. On the positive side, while hydroelectric dams require a large initial investment, once a dam is built, hydropower is one of the cheapest forms of electricity. The estimated average lifetime costs of hydropower electricity range from about $\$ 0.02$ per $\mathrm{kWh}$ to $\$ 0.20$ per kWh. ${ }^{18}$

\section{Solar Energy Costs}

João turned to his attention to solar energy systems. In the past, the cost of solar energy systems was prohibitive, but with new technology and third-generation solar cells, using solar energy systems had become more economically feasible. From 2010 to 2018, the cost of solar installations in the United States decreased by over 65 percent. ${ }^{19}$ In 2018 , a $150 \mathrm{~W}$ solar panel cost $\mathrm{R} \$ 500$ (U.S. $\$ 134){ }^{20}$

The cost of batteries was also decreasing. Energy storage capabilities afforded by batteries were an essential part of solar energy systems because the sun shines only during the day, and electricity demand was often higher at night. Battery capacity and cost were historically two of the leading reasons large-scale solar panel systems were less frequently utilized. In 2018, a 150 ampere-hour (Ah) battery cost R $\$ 1,053$, (U.S.) $\$ 283),{ }^{21}$ but the cost of batteries was decreasing quickly at an expected annual rate of 8 percent through $2022 .^{22}$

For a solar energy microgrid, the panels, inverters, and batteries needed to be purchased before any power could be generated, meaning solar would be a large upfront investment for Energisa. Many Pantanal residents could not afford the large up-front costs associated with solar electricity systems, which was why nonprofits had funded past Pantanal solar projects. After Energisa's initial investment, there would be maintenance costs associated with this microgrid, and proper maintenance was essential to achieve maximum efficiency. If part of the system were damaged or not functioning, the system would generate electricity poorly, or worse, the life span of the expensive batteries would be greatly reduced, and they would have to be replaced more frequently.

In addition, a local Porto Jofre resident would need to be trained to recognize problems and fix minor issues with the system. Further, if there were major issues with the system, a professional would need to travel from the local city of Cuiabá to Porto Jofre to fix it. Arranging this travel could be difficult, especially in the wet season, so having a local technician was imperative.

Since Energisa had not funded solar microgrids before, João was unsure if Energisa would impose a fee for the electricity residents used. One benefit of charging Porto Jofre residents a reasonable fee for electricity access would be that it could fund maintenance of the solar microgrid. On the other hand, some residents of Porto Jofre might not be able to afford even a small fee, so such fees could prevent them from having access to electricity.

\section{New Frontier}

In the past, the government of Brazil had neither funded community solar systems nor subsidized personal solar systems. The Brazilian government's reluctance to fund these projects was due to the newness of the technology, the high costs of panels, and the existing infrastructure. As the cost of 
these systems went down, and technology improved, solar microgrids had become a more viable option.

If João chose to use his Luz para Todos funding to invest in a community solar energy system, he would be taking a risk-and blazing a new trail. Choosing solar would likely face some backlash, but he could also pave the way for the government to invest in more solar panel microgrids. Since this would be a new option, he would have to create the format for applications. This route would certainly be more difficult, but João could serve as a pioneer for new renewable government options for electricity.

\section{Decision Time}

After days of research, João had learned about the technical process of generating electricity for solar microgrids and expanding the city grid line. He had learned about the various pros and cons of each type of system. Now the time had come for him to make a decision. He knew, as the leader of the Energisa committee, that he had a great deal of influence, and that the type of electricity infrastructure he endorsed would likely be the one that was built.

João's decisions would affect the lives of everyone in Porto Jofre and along the Transpantaneira Highway. These were people who provided the government with the tax money needed to fund these development projects and who had helped him build the career and life he led. It was now time for him to change their lives by expanding energy access to Porto Jofre.

Based on the information used to compare the various energy solu- tions, students should now possess the knowledge to make an informed decision about this situation. At this juncture, they are asked to use this information to think critically and form an opinion on João's decision. They are asked to consider all the factors of the situation and decide how Joao should proceed: Should he invest in solar microgrids or expansion of the city grid line?

\section{Author Disclosure Statement}

No competing financial interests exist.

\section{References}

1. U.S. Energy Information Administration. How Much Electricity Does an American Home Use? Oct. 2, 2019. www.eia.gov/tools/faqs/faq. php?id=97\&t=3 (last accessed 6/02/ 2020).

2. The World Bank. Access to Electricity. https://data.worldbank.org/ indicator/eg.elc.accs.zs (last accessed 6/02/2020).

3. Programa de Electrificação Rural. O Programa (Rural Electrification Program). https://www.mme.gov.br/ luzparatodos/Asp/o_programa.asp (last accessed 6/04/2020).

4. U.S. Energy Information Administration. Hydropower Supplies More Than Three-Quarters of Brazil's Electric Power. Today in Energy, June 17, 2014. www.eia.gov/todayinenergy/ detail.php?id=16731 (last accessed 6/02/2020).

5. World Nuclear Association. Comparison of Lifecycle Greenhouse Gas Emissions of Various Electricity Generation Sources. 2011. http:// www.world-nuclear.org/uploaded Files/org/WNA/Publications/Working Group_Reports/comparison_of_life cycle.pdf (last accessed 6/02/2020).

6. Climate Action Tracker. Brazil. Dec. 2, 2018. climateactiontracker. org/countries/brazil/pledges-andtargets/ (last accessed 6/02/2020).
7. Fearnside P. How a dam building boom is transforming the Brazilian Amazon. Yale Environment 360, Yale School of Forestry \& Environmental Studies, Sept. 26, 2017. e360.yale.edu/features/how-a-dambuilding-boom-is-transforming-thebrazilian-amazon (last accessed 6/02/ 2020).

8. Knier G. How Do Photovoltaics Work? National Aeronautics and Space Administration, NASA Science, Aug. 6, 2008. science.nasa. gov/science-news/science-at-nasa/ 2002/solarcells (last accessed 6/02/ 2020).

9. Northern Arizona Wind \& Sun. Solar Charge Controller Basics. www .solar-electric.com/learning-center/ batteries-and-charging/solar-chargecontroller-basics.html (last accessed 6/02/2020).

10. Than K. Critical Minerals Scarcity Could Threaten Renewable Energy Future. Stanford Earth, School of Earth, Energy and Environmental Science, Stanford University, Jan. 2018. earth.stanford.edu/news/criticalminerals-scarcity-could-threatenrenewable-energy-future (last accessed 6/02/2020).

11. Shellenberger M. If solar panels are so clean, why do they produce so much toxic waste? Forbes, May 23, 2019. www.forbes.com/sites/ michaelshellenberger/2018/05/23/ifsolar-panels-are-so-clean-why-dothey-produce-so-much-toxic-waste/ \#3eaa3f6f121c (last accessed 6/02/ 2020).

12. World Weather Online. Pantanal, Brazil Yearly Monthly Climate Weather Averages. www.worldweather online.com/lang/en-us/pantanalweather-averages/mato-grosso/br.aspx (last accessed 6/02/2020).

13. LatLong.net. Latitude and Longitude Finder, Pantanal, Mato Grosso, Brazil. ww.latlong.net/place/ pantanal-mato-grosso-brazil-4113. html (last accessed 6/02/2020). 
14. Queiroz de Oliveira G, Augusto Biscaro G, da Silva Lopes A, et al. Comparison between global solar radiation models in Aquidauana, 'Alto Pantanal' Region, Brazil. Comunicata Scientiae 2014;5(3):222-228.

15. The World Bank. Electric Power Transmission and Distribution Losses (\% of Output). IEA Statistics, 2018. data.worldbank.org/indicator/ EG.ELC.LOSS.ZS (last accessed 6/ 02/2020).

16. Climates to Travel, World Climate Guide. Climate-Pantanal. www.climatestotravel.com/climate/ brazil/pantanal (last accessed 6/02/ 2020).

17. Costa HS, and Costa RAL. Anlise Comparativa Econômica entre Diferentes Opções para a Eletrificação Domiciliar Rural (Comparative Economic Analysis between Different Options for Rural Household Electrification). Banco do Nordeste, Revista Econômica do Nordeste. Fortaleza 2000;31(3):320-328. https://
www.bnb.gov.br/projwebren/Exec/ artigoRenPDF.aspx?cd_artigo_ren=167 (last accessed 6/04/2020).

18. International Renewable Energy Agency (IRENA). IRENA working paper. Renewable Energy Cost Analysis Series. Hydropower, June 2012, vol. 1, Power Sector, issue 3/5. https://www.irena.org/document downloads/publications/re_technologies cost_analysis-hydropower.pdf (last accessed 6/02/2020).

19. Solar Energy Industries Association. Solar Industry Research Data. www.seia.org/solar-industryresearch-data (last accessed 6/02/ 2020).

20. Energia Total-Energia Solar. Painel Solar Fotovoltaico 150W Yingli YL150P-17b (Yingli YL 150P17b 150W Photovoltaic Solar Panel). www.energiatotal.com.br/painel-solarfotovoltaico-150w-yingli-yl150p-17b (last accessed 6/02/2020).

21. Energia Total-Energia Solar. Bateria Estacionária Moura No-
break-150Ah (Moura Nobreak Stationary Battery-15Ah). www. energiatotal.com.br/bateria-estacion \%C3\%A1ria-moura-nobreak-150ah (last accessed 6/02/2020).

22. Wood Mackenzie. Editorial. U.S. Front-of-the-Meter Energy Storage System Prices 2018-2022, May 9, 2018. www.woodmac.com/ourexpertise/focus/Power-Renewables/ U.S.-Front-of-the-Meter-EnergyStorage-System-Prices-2018-2022/ (last accessed 6/02/2020).

Address correspondence to: Dr. Adam C. Simon Department of Earth and Environmental Sciences University of Michigan 1100 N. University Avenue Ann Arbor, MI 48109 USA

E-mail:simonac@umich.edu 